\title{
Trivsel i kroppsøvingsfaget blant elever med lavt og høyt oksygenopptak
}

\author{
$\varnothing_{\text {yvind Bjerke }}{ }^{1 \star}$, Idar Kristian Lyngstad ${ }^{2}$, and \\ Pål Arild Lagestad ${ }^{2}$ \\ ${ }^{1}$ NTNU, Fakultet for larer- og tolkeutdanning, Trondheim, Norge; ${ }^{2}$ Nord Universitet, \\ Avdeling for larerutdanning, Levanger, Norge
}

\section{Sammendrag}

Tidligere studier indikerer at barn som er aktive på fritiden ser ut til å trives bedre $\mathrm{i}$ kroppsøving enn de mindre aktive. Denne studiens hensikt var å undersøke trivsel i kroppsøving for elever i norsk videregående skole med høy og lav fysisk form, målt gjennom oksygenopptak. Elevene hadde deltatt i et større longitudinelt forskningsprosjekt $(\mathrm{N}=69)$ hvor fysiologiske parametere (oksygenopptak, vekt, høyde) ble testet fra elevene gikk i 8 . trinn til og med 2. klasse på videregående skole. Elevene hadde også hvert år besvart en spørreundersøkelse om kroppsøving og fysisk aktivitet. Et utvalg på 26 elever i slutten av 2. år på videregående skole ble intervjuet om trivsel i kroppsøvingsfaget, der 13 av elevene hadde lavt oksygenopptak og 13 elever hadde høyt oksygenopptak. Spørreundersøkelsen ble analysert på de samme elevene. De kvantitative analysene viste ingen signifikante forskjeller mellom elever med lav og høy fysisk form når det gjaldt trivsel i kroppsøving, men de med høy fysisk form trivdes bedre i trening og idrett på fritiden. De kvalitative analysene tyder også på at begge elevgruppene trivdes i kroppsøving, men med ulike deler av faget. Elevgruppen med høy fysisk form opplevde trivsel i de fleste aktivitetene og ville ha timene som en treningsøkt. Elevene med lav fysisk form anså faget som et praktisk avbrekk i dagen og trivdes i aktiviteter som øvde delferdigheter, men ikke konkurranser eller øvelser som stilte krav til fysisk form.

Nøkkelord: Kroppsøving; fysisk form; videregående skole; velvare

\begin{abstract}
This study investigate students' well-being in physical activity, dividing the students into groups of high or low physical fitness based on maximal oxygen uptake. The students had participated in a larger longitudinal project from $8^{\text {th }}$ grade to their second year at Upper Secondary school. In the present study, 26 students at the end of their second year were selected, where 13 students had high oxygen uptake and 13 students had low oxygen uptake. These students were interviewed and fulfilled a survey about their motivation in physical education. The quantitative results indicate no difference in the students well-being. The qualitative results are supporting some of these findings, but these results reveal that the well-being was perceived differently according to students' physical fitness. Students with high oxygen uptake expected and experienced physical education lessons as exercises to become more fit, being comfortable in most activities. Students with lower oxygen uptake viewed upon physical activity as a practical break during the day, where they could be comfortable and practice on parts of the exercise.
\end{abstract}

^Korrespondanse: Øyvind Bjerke, NTNU, Fakultet for lærer- og tolkeutdanning, Norge. E-post: oyvind.bjerke@ntnu.no 
Øyvind Bjerke et al.

Keywords: Physical education; physical fitness; upper secondary school; well-being

Received: January 2016; Accepted: March 2016; Published: April 2016

\section{Innledning}

Det er en økende nasjonal bekymring at barn og unge ikke oppfyller målsettingene for daglig fysisk aktivitet (Kolle, Stokke, Hansen \& Andersen, 2012). Skolen har fătt noe av ansvaret for å få barn og unge aktive. Kroppsøvingens formål er å inspirere og øke bevegelsesgleden til å drive fysisk aktivitet hos elevene (Utdanningsdirektoratet, 2015). Det hevdes at deltakelse i kroppsøving øker sannsynligheten for at man vil bevege seg senere i livet (Kirk, 2005), og av den grunn er det viktig å ivareta trivselen hos elevene i kroppsøving. I tillegg til helseaspektet argumenteres det også for at kroppsøving spiller en viktig rolle i elevenes danningsprosess, siden læringserfaringer med god kvalitet i tidlige år kan øke både den fysisk-motoriske kompetansen og den underliggende motivasjonen som er viktig for videre fysisk aktiv livsstil (Ommundsen, 2013). Til forskjell fra den organiserte idretten, møtes alle barn og unge i skolen, og kroppsøving representerer dermed en kontekst hvor elevene kan bli eksponert for biologiske, sosiale og psykologiske ulikheter (Biddle \& Asare, 2011). Mangfoldet av elever gjør kroppsøvingsfaget til en unik arena, og ulikhetene gjenspeiles også i elevenes motivasjon og trivsel i faget.

For å bli inspirert til kroppslig bevegelse, poengterer kroppsøvingsfagets læreplan nødvendigheten av å oppleve glede og mestring (Utdanningsdirektoratet, 2015). Dette støttes av forskning som hevder at deltakelse i bevegelsesaktiviteter over tid, krever en viss grad av trivsel (Dismore \& Bailey, 2011). Det brukes flere begrep om elevenes trivsel i kroppsøving. Et begrep som kobles til trivsel, er «well-being», som kan defineres som «optimal psychological functioning and experience» (Ryan \& Deci, 2001, s. 142). Andre begrep som brukes i litteraturen, er «attitudes», eller holdning, samt motivasjon (Säfvenbom, Haugen \& Bulie, 2014; Kjønniksen, Fjørtoft \& Wold, 2009). Felles for begrepene er at de beskriver hva som driver elevene til å være fysisk aktive. Begrepene holdning og motivasjon har vært spesielt interessante å studere innenfor kroppsøving, fordi det kan hevdes at disse begrepene er i nær relasjon til fagets formål om å skape en livslang bevegelsesglede (Dismore \& Bailey, 2011), mens trivsel er mer et norsk begrep.

Det er flere studier som har undersøkt elevenes trivsel i kroppsøving. I en nylig studie basert på 2010 elever viste det seg at $44 \%$ av elevene ikke var fornøyd med hvordan kroppsøvingsundervisningen foregikk (Säfvenbom et al., 2014). 12\% av elevene likte ikke faget, mens 32\% likte ikke måten faget ble formidlet på. Nevnte studie viser at elever som er involvert i idrettskonkurranser på fritiden, opplever større grad av trivsel i kroppsøving enn elever som ikke deltar i slike konkurranser. Dette samsvarer med lignende nasjonale og internasjonale studier (Biddle, Atkin, Cavill \& Foster, 2011; Larson \& Redelius, 2008; Flagestad \& Skisland, 2008). Det ser ut til at gutter trives bedre, mestrer aktivitetene bedre og er mer fornøyd med innholdet av timene i kroppsøving enn hva jenter er (Kaj, Saint-Maurice, Karsai, Vass \& Csányi, 
2015; Gao, 2009; Rishovd, 2013). Noe av årsaken kan være at aktivitetene har for mye fokus på konkurranse (Johansen \& Andrews, 2005; Ommundsen \& Kvalø, 2007).

Koblingen mellom kroppsøving og idrett er vanlig siden idrett også er en del av kroppsøvingsfaget, blant annet beskrevet som eget hovedområde i læreplanen (Utdanningsdirektoratet, 2015). At idrettssterke trives bedre, kan indikere at kroppsøving oppfattes som opplæring i idrettsaktiviteter i stor grad (Kirk, 2010). Denne oppfatningen synes også å være tydelig hos de som utdannes til kroppsøvingslærere (Moen, 2011). Dersom elevene får drive med idrettsaktivitet som de kjenner igjen fra fritiden i kroppsøvingstimene, øker både evne, tro og forventninger om å lykkes i undervisningen (Säfvenbom et al., 2014; Gao, 2009). Elever som mangler positive erfaringer fra undervisning eller organisert idrett, kan få negative assosiasjoner til kroppsøving og oppleve mistrivsel i undervisningen dersom samme type aktiviteter gjennomføres i kroppsøving. Studier viser at elevene bruker ord som «hat»i beskrivelsen av faget (Olafson, 2002; Johansen \& Andrews, 2005). Basert på disse studiene kan det være grunn til å tro at trivsel i kroppsøving vil være særdeles viktig hos elever som ikke deltar i organisert idrett ellers, slik at de motiveres til en aktiv livsstil på sikt.

Den fysiske formen ser ut til å ha betydning for hvordan elevene oppfatter kroppsøvingsfaget. Elever som er i god fysisk form, har stor tro på egne ferdigheter i kroppsøving (Gao, 2009). I en nyere studie er sammenhenger mellom fysisk kapasitet og holdning til kroppsøving hos ungdommer undersøkt gjennom 5 ulike faktorer (Kaj et al., 2015). Resultatene fra studien viste at elever med god fysisk kapasitet har en mer positiv holdning til kroppsøving enn elever med lavere fysisk kapasitet. Frykten for å mislykkes minsker også med økt fysisk kapasitet. Studien antyder at det kan være forskjeller i hvordan elever med ulik fysisk form opplever kroppsøving og trives i timene. Den faktoren som ser ut til å bety aller mest for trivselen, er at kroppsøving oppleves som artig og lystbetont (Dismore \& Bailey, 2011). Grad av autonomi betyr mye for trivselen i kroppsøving (Ward, Wilkinson, Graser \& Prusak, 2008), noe studier med utgangspunkt i Deci \& Ryans selvbestemmelsesteori viser (Deci \& Ryan, 2000; Ryan \& Deci, 2000).

Ut fra disse tidligere funnene vil en nærliggende hypotese derfor være at elever som er i god fysisk form vil trives bedre i kroppsøving enn elever som er i dårlig fysisk form. Det syns å være godt dokumentert at det er sammenhenger mellom deltakelse i organisert idrett på fritiden og trivsel i kroppsøvingsfaget. I den senere tid har antall elever som deltar i uorganisert aktivitet på fritiden, økt i antall (Seippel, 2005), og slik sett kan det være grunn til å tro at elever som deltar i uorganisert idrett også kan være i god fysisk form. Det er derfor interessant å finne ut av hvordan elevene opplever kroppsøving og trives med faget ut fra fysisk form. Målet med studien er å belyse om det er forskjeller i opplevd trivsel i kroppsøvingsfaget mellom elever med høy og lav fysisk form, samt belyse hva som kjennetegner trivselen i kroppsøving blant elever med lav og høy fysisk form. 


\section{Metode}

For å belyse forskjeller mellom lav og høy fysisk form og trivsel i kroppsøving, ble det brukt tilgjengelige upubliserte spørreskjemadata om trivsel i kroppsøving blant et utvalg elever $\mathrm{i}$ videregående skole. Vi valgte også å inkludere rapportering om trivsel på flere arenaer i skole og fritid for å kunne sammenligne trivsel i kroppsøving med trivsel på andre arenaer. Ved at svarene ble utledet av de samme spørsmålene og svaralternativene, kunne resultatene til en viss grad generaliseres. For å fange opp flere dimensjoner av trivsel i kroppsøving ble kvalitativ metode ved hjelp av intervjuer benyttet til datainnsamling. En slik tilnærming gjorde det mulig å belyse grad av trivsel, samt eventuelle forskjeller mellom de to elevgruppene, ut fra flere åpne spørsmål. Dersom fortolkningen omkring grad av trivsel i de kvalitative analysene var i samsvar med de kvantitative analysene, ville troverdigheten av de kvalitative resultatene styrkes. I tillegg var kvalitative intervjuer nødvendig for å belyse forskningsspørsmålet om hva som kjennetegnet trivselen i kroppsøving blant elever med lav og høy fysisk form.

\section{Utvalg}

Utvalget bestod av 26 elever som var i sitt andre år i videregående skole. Elevene hadde deltatt $i$ et større longitudinelt forskningsprosjekt der 6 klasser med 139 elever ble valgt ut ved oppstart. 124 av disse elevene ønsket å delta i studien der 81 elever gjennomførte alle målingene. I studien ble det målt elevenes oksygenopptak, deres aktivitetsmønster og trivsel ifra 8. klasse i grunnskolen og gjennom alle skoleår til og med videregående skole, og 81 elever gjennomførte studien. De 81 elevene hadde nylig gjennomført oksygenopptaksmålinger og fylt ut spørreskjema da den oppfølgende intervjustudien ble initiert, hvorav 69 elever hadde kroppsøving. Oksygenopptaksmålingene ble gjennomført etter standardiserte prosedyrer (se Tillaar, Rangul \& Lagestad, 2016). Av disse 69 elevene ble 26 elever valgt ut til en intervjustudie med en stratifisert tilnærming hvor kroppsøvingselevene med lavest og høyest oksygenopptak fra begge kjønn ble valgt ut. Elever som ikke hadde kroppsøving, dvs. utdanningsprogram for idrettsfag og utdanningsprogram for musikk, dans og drama, ble ekskludert fra studien. En cutoff lik Young-HUNTs inndeling (Nes, Østhus, Welde, Aspenes \& Wisløf, 2013) ble benyttet, slik at elevene med lavt oksygenopptak hadde samme skåre som Nes et al. (2012) definerte som lav fysisk form for en større populasjon. Samme prosedyre ble benyttet for elevgruppen med høyt oksygenopptak. Oksygenopptaket ble valgt som en indikator på fysisk form, da dette er betraktet som den beste objektive indikatoren for aerob utholdenhet (Åstrand \& Rodahl, 2003). Når elevenes oksygenopptak ble sammenlignet med hverandre, ble verdiene skalert og gjort vektuavhengig ved å dividere oksygenopptaket på $\mathrm{kg}^{-0,67}$ i henhold til anbefalinger (Nes et al., 2012). Inndelingen i gruppene lav og høy fysisk form er basert på det vektuavhengige oksygenopptaket. Elevene i de to gruppene hadde signifikant forskjellig oksygenopptak $(\mathrm{t}=-4.73, \mathrm{p}=0,000)$. Både tradisjonelt oksygenopptak $\left(\mathrm{ml} \cdot \mathrm{kg}^{-1} \cdot \mathrm{min}^{-1}\right)$ og vektuavhengig oksygenopptak $\left(\mathrm{ml} \cdot \mathrm{kg}^{-0,67} \cdot \mathrm{min}^{-1}\right)$ er gjengitt i tabell 1 . 
Tabell 1. Oversikt over oksygenopptak med standardavvik i de to gruppene, samt fordeling mellom kjønn

\begin{tabular}{|c|c|c|c|c|}
\hline & \multicolumn{2}{|c|}{$\mathrm{VO}_{2 \mathrm{maks}}=\left(\mathrm{ml} \cdot \mathrm{kg}^{-1} \cdot \mathrm{min}^{-1}\right)$} & \multicolumn{2}{|c|}{$\mathrm{VO}_{2 \text { maks }}=\left(\mathrm{ml} \cdot \mathrm{kg}^{-0,67} \cdot \mathrm{min}^{-1}\right)$} \\
\hline & Lav fysisk form $\mathrm{N}=13$ & Høy fysisk form $\mathrm{N}=13$ & Lav fysisk form $\mathrm{N}=13$ & Høy fysisk form $N=13$ \\
\hline Total & $42,6 \pm 8,5$ & $56,4 \pm 7,9$ & $172,2 \pm 28,8$ & $230,1 \pm 34,2$ \\
\hline Gutter & $\begin{array}{c}49,6 \pm 4,6 \\
\mathrm{~N}=6\end{array}$ & $\begin{array}{c}61,1 \pm 7,1 \\
\mathrm{~N}=7\end{array}$ & $\begin{array}{c}198 \pm 10,8 \\
\mathrm{~N}=6\end{array}$ & $\begin{array}{c}257 \pm 18,8 \\
\mathrm{~N}=7\end{array}$ \\
\hline Jenter & $\begin{array}{c}36,7 \pm 6,1 \\
\mathrm{~N}=7\end{array}$ & $\begin{array}{c}50,9 \pm 4,8 \\
\mathrm{~N}=6\end{array}$ & $\begin{array}{c}149 \pm 15,7 \\
\mathrm{~N}=7\end{array}$ & $\begin{array}{c}200 \pm 16,5 \\
\mathrm{~N}=6\end{array}$ \\
\hline
\end{tabular}

De to jentegruppene hadde signifikant forskjellig fysisk form $(t=-5,67$, $p=0,001)$, det samme gialdt de to guttegruppene $(t=-6,69 ; p=0,000)$. Elevene i gruppen med lav fysisk form oppgav også mindre anstrengende daglig fysisk aktivitet, med gjennomsnittlig en dag i uken, mens elevene med høy fysisk form oppgav anstrengende fysisk aktivitet flere ganger i uken. Elevene i de to gruppene viste seg å være likt fordelt når det gjaldt studiespesialiserende studieretning og yrkesfag, henholdsvis 4 og 9 fra hver gruppe.

\section{Innsamling av data}

Spørreskjemaet omfattet selvrapportert trivsel og fysisk aktivitet. De kvantitative dataene (upubliserte) var allerede tilgjengelig gjennom det longitudinelle forskningsprosjektet. For å samle inn de kvalitative dataene gjennom intervju ble det valgt en induktiv tilnærming, da det $\mathrm{i}$ tråd med en fenomenologisk tilnærming syntes formålstjenlig å bruke åpne spørsmål for å få frem elevenes egne opplevelser og erfaringer med kroppsøvingsfaget. Spørsmålene ble organisert $\mathrm{i}$ en semistrukturert intervjuguide (Kvale \& Brinkman, 2009). Det ble vektlagt å benytte oppfølgende spørsmål på informantenes svar, og helt til slutt i intervjuet ble det åpnet opp for at informantene fikk komme med innspill. Intervjuene fant sted i løpet av våren 2014, da elevene var i slutten av sitt andre år på videregående skole. Hver informant ble intervjuet én gang, og intervjuene tok mellom 45 og 60 minutter. Gjennomføringen av studien var godkjent av personvernombudet for forskning (NSD), og fulgte forskningsetiske standarder $\mathrm{i}$ forhold til frivillighet, anonymitet og konfidensialitet.

\section{Analyse av data}

For å belyse forskjeller i trivsel mellom gruppene med lav og høy fysisk form ble det benyttet kji-kvadrat test. Signifikansnivået var satt til $p<0,05$ for gruppeforskjellene når det gjaldt trivsel på skolen og på fritiden. Statistiske analyser ble utført i SPSS versjon 21.0 (SPSS, Inc., Chicago, IL, USA). Den metodiske tilnærmingen i de kvalitative analysene legger opp til å få tak i den felles opplevelse de to gruppene har når det gjelder det samme fenomenet gjennom samtale med forskningsdeltakerne slik 
Postholm (2010) beskriver det. Intervjuene ble transkribert ordrett og videre analysert i det kvalitative analyseprogrammet Nvivo 10, som bidro til å strukturere funnene (Klemp, 2012). Elever fikk pseudonymer i form av navn med 3-4 bokstaver for de som hadde lavt oksygenopptak, og navn på 5-6 bokstaver for elever med høyt oksygenopptak. Dette for å kunne identifisere elever med lavt og høyt oksygenopptak. Transkripsjonene ble lest gjennom flere ganger, og underveis ble det laget kategoriseringer ut fra tolkninger av elevenes utsagn (Kvale \& Brinkmann, 2009). Her ble det laget underkategorier som omhandlet elevenes trivsel i kroppsøving. Data ble meningsfortettet ved at sitater og kortere avsnitt ble plukket ut fra intervjuutskriftene og plassert sammen innenfor samme analyseenhet. Deretter gjentok prosessen seg med å systematisere funnene under hver analyseenhet. At tre forskere har bidratt i denne fortolkningsprosessen, er med på å øke troverdigheten av de kvalitative resultatene. For å minimere forforståelsen har forskerne lest hele transkripsjonen og diskutert seg imellom hvorvidt fortolkningen kan være riktig.

\section{Resultat}

I tabell 2 fremkommer eventuelle kvantitative forskjeller i trivsel på skole, i idrett og på fritiden mellom de med lavt og høyt oksygenopptak.

Tabell 2 viser at når det gjelder oppgitt trivsel, opplever de med høy fysisk form å trives bedre på treninger og i idrettskonkurranser sammenlignet med gruppen med lav fysisk form. Det er imidlertid ingen signifikant forskjell mellom gruppene når det gjelder den oppgitte trivselen i kroppsøving, i friminuttene, i skoletimene eller i forhold til det å være andpusten. Det er heller ingen signifikant forskjell mellom gruppene når det gjelder den oppgitte trivselen med venner, trivselen hjemme eller trivsel ved å se på TV.

Tabell 2. Forskjell i oppgitt trivsel mellom de med lavt og høyt oksygenopptak $(\mathrm{N}=26)$.

\begin{tabular}{lll}
\hline Aktivitet & (p-verdi) & \multicolumn{1}{c}{$\begin{array}{c}\text { Beskrivelse av forskjell mellom gruppene } \\
\text { med utgangspunkt i gjennomsnittsverdier }\end{array}$} \\
\hline $\begin{array}{l}\text { Trivsel i gymtimene } \\
\text { Trivsel i friminuttene }\end{array}$ & $\mathrm{p}=0,178$ & $\begin{array}{l}\text { Ingen signifikant forskjell, de fleste trives godt } \\
\text { Trivsel i de fleste skoletimene }\end{array}$ \\
$\begin{array}{ll}\text { Trivsel på treninger } \\
\mathrm{p}=0,620\end{array}$ & $\begin{array}{l}\text { Ingen signifikant forskjell, de fleste trives godt } \\
\mathrm{p}=0,009\end{array}$ & $\begin{array}{l}\text { Høy: Alle trives svært godt } \\
\text { Lav: De fleste trives svært godt }\end{array}$ \\
Trivsel i idrettskonkurranser & $\mathrm{p}=0,010$ & Høy: Alle trives svært godt \\
Trivsel når jeg er andpusten & $\mathrm{p}=0,229$ & $\begin{array}{l}\text { Lav: De fleste trives godt } \\
\text { Ingen signifikant forskjell, de fleste trives godt }\end{array}$ \\
Trivsel med venner & $\mathrm{p}=0,953$ & Ingen signifikant forskjell, de fleste trives svært godt \\
Trivsel hjemme & $\mathrm{p}=0,559$ & Ingen signifikant forskjell, de fleste trives godt \\
Trivsel når jeg ser på TV & $\mathrm{p}=0,568$ & Ingen signifikant forskjell, de fleste trives godt
\end{tabular}


De kvalitative resultatene viser at elever med høy og lav fysisk form trives med forskjellige deler av kroppsøvingsfaget. Elevene med høy fysisk form trives tilsynelatende med all type aktivitet, mens trivselen spriker mer blant elever med lav fysisk form. Ut fra analysene i denne studien ser det ikke ut til at trivselen i kroppsøving er kjønnsrelatert. Resultatene beskrives i form av tre ulike trivselskategorier ut fra meningsfortettingen hos respondentene. Den første kategorien belyser trivsel i forhold til fagets formål. Den andre kategorien beskriver trivsel i relasjon til innhold og arbeidsmåter i kroppsøvingstimene, mens den tredje omhandler elevenes trivsel med kroppsøving sammenlignet med andre fag. Kategoriene presenteres ved hjelp av tre overskrifter hvor hovedfunnene tydeliggiøres.

\section{Trivsel gjennom ekstra treningsøkt eller som avbrekk fra en teoretisk hverdag}

Elever med høy fysisk form ønsker at kroppsøvingsfaget skal gi dem trening, og gjerne gjennom høy hjertefrekvens. De forventer at kroppen skal brukes og at de skal bli svette etter timen. Elevene uttrykker trivsel med å få et innhold på timen hvor de kjenner at kroppen har blitt brukt til fysisk aktivitet. Kroppsøvingstimen omtales av de med høy fysisk form som en treningsøkt, og ikke time. På spørsmålet «Kan du beskrive ditt forhold til kroppsøving?» svarer Oleander: «Det er veldig artig å ha gym. Det at du giør det på skolen gjør at du får en ekstra treningsøkt også.» Når Eivind blir bedt om å utdype hva han trives med, så sier han det slik: «Ja, det er selvsagt hardtreningen jeg liker.»

Elevene med høy fysisk form oppgir trivsel med å være fysisk slitne både $\mathrm{i}$ hverdagen generelt og i kroppsøvingsundervisninga spesielt. Det er ingen elever som nevner at trivsel knyttes til læring i kroppsøvingsfaget, det er først og fremst følelsen av å bli fysisk sliten elevene fremhever som viktig. Utsagnene synes å gjelde for både gutter og jenter, noe Therese eksemplifiserer:

Det er greit å ha noe der man får brukt seg selv litt. Være i skikkelig aktivitet og bli litt svett. Enkelte ganger så blir jeg ikke det og da føler jeg ikke at gymtimen har vært noen gymtime.

Elevene med lav fysisk form på sin side beskriver kroppsøvingsfaget som en avkobling og et avbrekk fra en teoretisk hverdag i større grad enn elever med høy fysisk form. Dette eksemplifiseres med Tines utsagn: «[...] for det er jo litt godt å få ha litt anna inn i skoletiden og, enn bare fag. Du får gjør noe annet, du får et avbrekk på en måte og får liksom tenke på noe annet.» Også Lise fremhever at «jeg synes det har vært et veldig fint avbrekk fra ellers veldig teoretiske fag.» Jens opplever også at kroppsøvingsfaget er et godt avbrekk, og at det hjelper han med å føle seg mer opplagt til timene etterpå: «Da er jeg såpass sliten så jeg får til å følge med mer. Slipper tanken på at jeg må røre meg, at jeg må ut, og uro i føttene».

\section{Trivsel i aktivitetene - artige eller kjedelige aktiviteter}

Den andre trivselskategorien er forbundet med fagets innhold og undervisningsformer og beskriver elevenes oppfatninger av hvordan timen organiseres og valg av øvelser. 
Når Eli blir bedt om å nyansere hvorfor hun ikke trives så veldig godt i kroppsøvingstimene, og om det er aktivitetsformer som skaper mindre trivsel enn andre, svarer hun: «Ja, for meg er det særlig ballspill som ikke fungerer i hele tatt. [. . .]. Når vi har løping så syns jeg det er artig.» Dette er et typisk eksempel på at aktivitetene klassifiseres ut fra om de er artige eller ikke. Ofte relateres denne trivselen opp mot hvorvidt de mestrer aktiviteten eller ikke. Oleander formulerer seg slik:

Gym er som sagt den artigste timen på skolen synes jeg, og spesielt ballspill da. Det har med hva du behersker da. Det er noe med det at når du behersker noe, så synes du det er artig.

Begge elevgrupper opplever noe trivsel i timene, men i ulike deler. Elever med lav fysisk form uttrykker mindre trivsel enn elever med høy fysisk form, og grad av trivsel har med valg av aktiviteter i timene å gjøre. Elevgruppen med lav fysisk form trives $\mathrm{i}$ hovedsak ikke i de delene av timen hvor de blir sammenlignet med andre, slik som i spillsekvenser og ved lagkonkurranser, stafetter og lignende. Elevene begrunner lavere trivsel med at de ikke behersker aktiviteten. Eli beskriver hvorfor hun ikke trives med ballspill og konkurranser:

Jeg opplever at det er veldig mye ballspill og sånne ting. Og det har jeg ikke peiling på i det hele tatt. Og så er det ganske mye konkurranse innad i klassen, [...] så hvis du er på et tapende fotballag, så er det ikke helt bra.

Selv om aktiviteter med konkurranseelement oppgis som en grunn til mistrivsel hos spesielt jenter med svak fysisk form, opplever flere av guttene med lav fysisk form trivsel i slike aktiviteter. Disse guttene opplever at de er en del av et sosialt fellesskap i kroppsøvingstimene, og at de kan regulere hvor mye de er aktive. Generelt trives denne elevgruppen bedre når det gjennomføres individuelle øvinger og delferdigheter. Eli, som ikke har så positiv opplevelse av kroppsøvingsfaget, beskriver det slik:

Jeg synes når vi går gjennom øvinger på delferdigheter og teknikk, så er det ganske greit, men når vi skal til med spilling, så er jeg ikke like god på dette. Jeg får det til når det er bare øving på delferdigheter, men når det blir blandet inn masse andre greier (spill), så får jeg det ikke til så bra.

De elevene som har lav fysisk form, oppgir å trives mindre når det blir satt krav til fysisk form, slik som det blir gjort når elevene må løpe langt eller testes, eksempelvis 3000 meter og 800 meter. Kortere distanse på 60 meter går imidlertid fint.

Noen av elevene trekker fram at de trives i timer som er godt organiserte. Hvis det er dårlig organisering eller for mye tull i timene, så oppgir enkelte elever at de trives dårligere. Aktivitetene må gjennomføres på en ordentlig måte, sier de. Noen elever forteller at noen spill og konkurranser fungerer best ved homogene lag hvor alle er interessert i aktiviteten. Therese utdyper dette på følgende måte:

Aktivitetene er kjedelig ...[...] med den motstanden du får. Og hvis vi skal spille fotball så er det ikke så veldig mange som kan spille på laget med deg. For de er liksom ikke på det samme nivået som meg selv da. 


\section{Trivsel med faget - et yndlingsfag eller et sosialt møtepunkt}

«Det er rett og slett yndlingsfaget mitt.» (Helene). Sitatet er hentet fra en av elevene med høy fysisk form og er typisk for hvordan elevene i denne gruppen omtaler kroppsøvingsfaget. Elevene med høy fysisk form trives veldig godt i kroppsøving og omtaler kroppsøving som «yndlingsfaget» eller «favorittfaget». De med lav fysisk form trives med deler av kroppsøvingsfaget. De fleste elevene i begge gruppene oppgir å trives med det sosiale som skapes i timene, som Tone: «Jeg tror det er det sosiale som gjør det artig egentlig. Artigere å holde på flere enn å være alene.» Også elever med høy fysisk form trekker fram den sosiale betydningen faget har. Det gjelder både i timene og i garderoben før og etter kroppsøving. Elevene oppgir at kroppsøving har en sosial verdi som ikke oppleves i samme grad gjennom andre fag. Harald sier det slik: «Det er med og viser andre sider av folk og du får holde på sammen på en annen måte. Det er med og skaper kameratskap og lagånd, og klassen blir sterkere.»

Tine oppgir å ha opplevd dårlig klassemiljø og beskriver hvordan hun opplevde at dette gikk ut over hennes deltakelse og trivsel i kroppsøving. Hun følte seg utfrosset av klassen, og av den grunn valgte hun å ikke delta i timene. Men læreren fikk til et bedre klassemiljø, og etter hvert trivdes hun bedre igjen. Tine trekker også fram det sosiale aspektet ved kroppsøving og hvordan man får vist seg frem fra en annen side i det praktiske faget enn hva man giør i teoretiske fag. På spørsmål om hva det skyldes at hun trives i faget, så svarer hun: «Det er vel litt miljøet, det at du føler du blir inkludert. For at hvis du ikke blir inkludert så er det ikke så artig å være med i kroppsøvingen.»

\section{Drøfting}

De kvantitative analysene viser ingen signifikante forskjeller mellom elever med lav og høy fysisk form når det gjelder trivsel i kroppsøving, og heller ikke når det gjelder trivsel i de fleste skoletimene eller friminuttene. Dette står i kontrast til trivselen i idrettsaktiviteter og på treninger, hvor de med høy fysisk form trives bedre. Dette er overraskende siden hypotesen i denne studien var at elever med høy fysisk form ville trives bedre enn elever med lav fysisk form. Dette går ut fra en antakelse om at kroppsøving består av mange idrettsrelaterte timer (Kirk, 2010), og at opplevd kompetanse kan være høyere hos elever med høy fysisk form (Gao, 2009). Funnet er også overraskende siden gruppen med høy fysisk form oppgir å trives bedre på treninger og i idrettskonkurranser sammenlignet med gruppen med lav fysisk form. Analysene fra de kvalitative dataene tyder altså på at forskjeller i grad av trivsel mellom elever med høy og lav fysisk form knytter seg til idrettsarenaen, og ikke til kroppsøving $\mathrm{i}$ skolen. Mindre trivsel oppstår dersom kroppsøvingsfaget blir for idrettslikt, med fokus på konkurranser og prestasjon. Øving av ferdigheter, derimot, ser ut til å gi trivsel hos begge elevgruppene.

De kvantitative dataene underbygger analysene $\mathrm{i}$ intervjudataene, som også viser at elever med høy og lav fysisk form opplever trivsel i kroppsøving, men de kvalitative dataene gir et mer nyansert bilde av elevenes trivsel. Analysen av intervjudataene viser 
at graden av trivsel begrunnes ut fra ulike aspekter av faget. Et interessant funn er at elever som har høy fysisk form, har forventninger om kroppsøvingstimen som en treningsøkt, mens elever med lav fysisk form ser på kroppsøving som et avbrekk fra en teoretisk skolehverdag. Elevene med høy fysisk form anser ikke kroppsøvingstimen som en ordentlig kroppsøvingstime hvis de ikke blir fysisk slitne. Det er ikke overaskende at elever med høy fysisk form trives godt i kroppsøvingstimer hvor de blir svette og andpustne, blant annet fordi innsats er en del av vurderingsgrunnlaget $i$ kroppsøving, men også fordi det er en forventning fra elevene om at å bli sliten er noe av fagets hensikt. Tidligere studier viser at en betydningsfull faktor for elevenes trivsel i kroppsøving, er opplevelsen av glede og mestring (Dismore \& Bailey, 2011) samt tro på egne evner (Gao, 2009). Denne elevgruppen forventer at undervisningen skal inneholde høy intensitet. Elever med lav fysisk form kan også se på kroppsøvingstimen som mosjon og trening, men her viser elevenes utsagn at de hovedsakelig ser på faget som et avkoblingsfag fra mye teoriarbeid i skolen. Elevene beskriver kroppsøving som et praktisk fag hvor de får vært i fysisk bevegelse, noe de anser som viktig og som de trives med.

Et annet funn i denne undersøkelsen er at trivsel er forbundet med hvorvidt aktivitetene i kroppsøving er artige eller kjedelige. Dette er ikke ulikt tidligere funn hvor elevene sier at de trives når aktivitetene er preget av glede og moro (Dismore \& Bailay, 2011). Elevene med høy fysisk form omtaler de fleste aktivitetene som artige, så for dem spiller dette muligens ikke så stor rolle, mens dette varierer i større grad hos elever med lav fysisk form. Elever med lav fysisk form trives når de øver på individuelle delferdigheter og i situasjoner hvor de ikke sammenlignes med andre. De oppgir trivsel når de mestrer øvelsene. Dersom organiseringen av timen er slik at elevene ikke blir eksponert for sammenligning av ferdigheter, bidrar dette også til å skape trivsel for elevene med svak fysisk form. Elevene med høy fysisk form vil gjerne yte i timene slik at de får fysisk utbytte, og dersom medelevene ikke yter nok motstand, oppleves aktiviteten som kjedelig, jamfør Thereses oppfattelse. Hvorvidt aktivitetene omtales som artige eller kjedelige, ser også ut til å ha sammenheng med elevens muligheter til å velge aktiviteter. Flere elever med lav fysisk form ønsket frihet til å velge aktiviteter, noe som gjenspeiler Deci og Ryans (2000) selvbestemmelsesteori, der autonomi er viktig for motivasjonen. Det samsvarer med tidligere funn som fremhever betydningen av medbestemmelse i kroppsøving (How, Whipp, Dimmock \& Jackson, 2013; Ward, Wilkinson, Graser \& Prusak, 2008). Slik sett nyanserer intervjuene de kvantitative funnene, hvor det ikke var signifikant forskjell mellom høy og lav fysisk form.

Elevene trekker fram at trivselen er sterkt knyttet til en mestringsfølelse, og til det som elevene beskriver som den gode følelsen av å få til noe. Tidligere undersøkelser på selvbestemt motivasjon trekker frem oppfattet kompetanse som en viktig faktor for den indre motivasjonen (Ferrer-Caja \& Weiss, 2000), noe som er et grunnleggende behov $i$ Selvbestemmelsesteorien (Deci \& Ryan, 2000). Vår studie viser at elevene med lav fysisk form ikke opplever mestring i øvelser hvor det kreves god fysisk form. Øvelser med langdistanseløp og tester, samt øvelser hvor elevene sammenlignes med andre elever, synes ikke å gi god trivsel. Derimot oppleves det å gjennomføre korte løp, styrketrening og aktiviteter der oksygenopptak ikke spiller så stor rolle som mer 
motiverende, og dette gir bedre trivsel. Det interessante her er at elevene med lav fysisk form synes å oppleve mestring ut fra egne forutsetninger. Det ser ikke ut som mestringsfølelsen oppstår på basis av sammenligning med de andre i gruppen. Det kan altså være andre faktorer som påvirker deres motivasjon, opplevelse av trivsel og deltakelse. Dette samsvarer med resultatene til Cox og Williams (2008), som fant at fysisk kompetanse ikke nødvendigvis er den viktigste komponenten for selvbestemt motivasjon. Støtte fra lærer, sosialt klima i klassen og tilhørighet i gruppen synes å være vel så viktig for hvorvidt elevene er motiverte og deltar eller ikke. Så selv om elevene kan ha et problematisk forhold til deler av kroppsøvingen, tyder analysen på at de trives med andre deler av faget, fordi de er en del av en gruppe som giør praktisk aktivitet sammen.

Selv om individuelle delferdigheter gir bedre trivsel, så fremheves viktigheten av det sosiale i faget, noe som kan virke paradoksalt. Dette betyr at den sosiale komponenten er at elevene deltar i den samme øvelsen, men elevene praktiserer øvelsen ulikt og individuelt. Selv om de utfører individuelle øvelser, så foregår dette i et fellesskap, og slik opplever elevene samhold og kameratskap. Elevenes opplevelse av tilhørighet støttes av Selvbestemmelsesteorien (Deci \& Ryan, 2000) hvor tilhørighet er et grunnleggende behov. Et eksempel kan hentes fra hvordan elevene $\mathrm{i}$ både lav og høy fysisk form opplevde trivselen i fotballaktiviteter. Begge elevgruppene opplevde at de til en viss grad kunne styre intensiteten selv ved å delta for fullt eller innta en mer passiv rolle. Å delta sammen med andre, være i et fellesskap, kan derfor sies å øke trivselen.

\section{Konklusjon}

I denne studien er elevenes trivsel i kroppsøving belyst ut fra ulik fysisk form, målt gjennom oksygenopptak. Mens den kvantitative analysen ikke avdekker statistiske forskjeller mellom de med lav og høy fysisk form, så nyanseres dette bildet i den kvalitative analysen av intervjudataene. Ved å både bruke kvalitativ og kvantitativ metode har vi avdekket hvordan elever med lav og høy fysisk form opplevde trivselen i kroppsøving. De kvantitative analysene viser at det ikke var signifikante forskjeller mellom elever med lav og høy fysisk form når det gjaldt trivsel i kroppsøving, i motsetning til treninger og idrettskonkurranser på fritiden, hvor de med høy fysisk form trivdes bedre. Nå kan det sies at de kvantitative funnene har begrensinger siden antallet er 26 elever. Likevel gir de kvalitative analysene interessante funn som er viktig å ta med seg i diskusjonen om kroppsøvingsfagets innhold. Analyser av intervjuene tyder imidlertid på at elevene med lav og høy fysisk form har ulik begrunnelse for sin trivsel i kroppsøving. Elever med høy fysisk form trivdes med det meste i kroppsøving, men spesielt med aktiviteter der de blir fysisk slitne og i aktiviteter med konkurranseaspekt og sosial sammenligning. Elever med lav fysisk form opplevde trivsel i øving på individuelle ferdigheter og i lagspill der de selv kan velge grad av involvering. Medbestemmelse syntes også å påvirke trivselen positivt for denne gruppen. På den annen side viser også studien hva som kan skape mistrivsel. Resultatene tyder på at det er måten kroppsøvingsfaget organiseres på og innholdet av undervisningen som kan påvirke trivselen blant elevene. Graden av trivsel ser ut til 
å være knyttet til fysisk form. De praktiske implikasjoner av funnene vil være at elevene tilbys aktiviteter hvor de øver på individuelle øvelser uten for mye sosial sammenligning, samt at det gis rom for medbestemmelse når det gjelder aktiviteter og organisering.

\section{Biografi}

Øyvind Bjerke er førstelektor i kroppsøving ved Fakultet for lærer- og tolkeutdanning, NTNU. Han er Cand.Polit ved NTNU innen idrettsvitenskap med spesialisering innen motorikk. Han har jobbet med lærerutdanning siden 2002, både praktisk og teoretisk, men har spesiell interesse innenfor ulike aspekter av læring. E-mail: oyvind.bjerke@ntnu.no

Idar Lyngstad er førsteamanuensis i kroppsøving ved Nord universitet, avdeling for lærerutdanning. Han har doktorgrad i pedagogikk fra NTNU og har publisert forskningsartikler innenfor fagdidaktikk i kroppsøving. Han har ledet Utdanningsdirektoratets arbeidsgruppe i kroppsøving i forbindelse med revisjon av læreplan i 2012 og bidratt i utviklingen av 5-årig grunnskolelærerutdanning som leder for en faggruppe i kroppsøving. E-mail: idar.k.lyngstad@nord.no

Pål Lagestad er dosent i kroppsøvings- og idrettsvitenskap ved Nord universitet, avdeling for lærerutdanning. Han har doktorgrad i idrettsvitenskap fra Norges idrettshøgskole, hovedfag i kroppsøving fra Høgskolen i NordTrøndelag, og hovedfag i sosiologi fra Universitetet i Tromsø. Han har publisert forskningsartikler i senere år innenfor idrettssosiologi og pedagogikk. E-mail: pal.a.lagestad@nord.no

\section{Referanser}

Biddle, S. J. H. \& Asare, M. (2011). Physical activity and mental health in children and adolescents: a review of reviews. British fournal of Sports Medicine, 45(11), 886-895.

Biddle, S. H., Atkin, A. J., Cavill, N. \& Foster, C. (2011). Correlates of physical activity in youth: a review of quantitative systematic reviews. International Review Of Sport $\mathcal{E}$ Exercise Psychology, 4(1), 25-49.

Cox, A. \& Williams, L. (2008). The Roles of Perceived Teacher Support, Motivational Climate, and Psychological Need Satisfaction in Students' Physical Education Motivation. Fournal of Sport E Exercise Psychology, 30(2), 222-239.

Deci, E. L. \& Ryan, R. M. (2000). The "What" and "Why" of Goal Pursuits: Human Needs and the SelfDetermination of Behavior. Psychology Inquiry, 11(4), 227-268.

Dismore, H. \& Bailey, R. (2011). Fun and Enjoyment in Physical Education: Young People's Attitudes. Research Papers in Education, 26(4), 499-516.

Ferrer-Caja, E. \& Weiss, M. R. (2000). Predictors of intrinsic motivation among adolescent students in physical education. Reasearch Quarterly for Exercise and Sport, 71(3), 267-279.

Flagestad, L. \& Skisland, J. O. (2008). Økt trivsel i kroppsøvingsfaget. I B. T. Johansen, R. Høigaard \& J. B. Fjeld (Red.), Nyere perspektiv innen idrett og idrettspedagogikk (s. 195-199). Kristiansand: Høyskoleforlaget.

Gao, Z. (2009). Students' Motivation, Engagement, Satisfaction, and Cardiorespiratory Fitness in Physical Education. Fournal of Applied Sport Psychology, 21, 102-115.

How, Y. M., Whipp, P., Dimmock, J. \& Jackson, B. (2013). The effects of choice on autonomous motivation, perceived autonomy support, and physical activity levels in high school physical education. Fournal of Teaching in Physical Education, 32(2), 131-148.

Johansen, V. \& Andrews, T. (2005). «Gym er det faget jeg hater mest». Norsk pedagogisk tidsskrift, 89(4), 302-314.

Kaj, M., Saint-Maurice, P., Karsai, I., Vass, Z. \& Csányi, T. (2015). Associations Between Attitudes Toward Physical Education and Aerobic Capacity in Hungarian High School Students. Research Quarterly for Exercise and Sport, 86(1), 74-81.

Kirk, D. (2005). Physical education, youth sport and lifelong participation: the importance of early learning experiences. European Physical Education Review, 11(3), 239-255.

Kirk, D. (2010). Physical Education Futures. London: Routledge.

Kjønniksen, L., Fjørtoft, I. \& Wold, B. (2009). Attitude to Physical Education and Participation in Organized Youth Sports During Adolescence Related to Physical Activity in Young Adulthood: A 10-year Longitudinal Study. European Physical Education Review, 15(2), 139-154. 
Klemp, T. (2012). Kvalitativ analyse og bruk av programvare. I V. Nilsen (Red.). Analyse $i$ kvalitative studier. Den skrivende forskeren (s.119-136). Oslo: Universitetsforlaget.

Kolle, E., Stokke, J. S., Hansen, B. H. \& Andersen, S. (2012). Fysisk aktivitet blant 6-, 9- og 15 åringer $i$ Norge. Resultater fra en kartlegging $i$ 2011. Helsedirektoratet.

Kvale, S. \& Brinkman, S. (2009). Det kvalitative forskningsintervju. 2.utgave. Oslo: Gyldendal Norsk Forlag.

Larson, H. \& Redelius, K. (2008). Swedish Physical Education Research Questioned-Current Situation and Future Directions. Physical Education and Sport Pedagogy, 13(4), 381-398.

Moen, K. M. (2011). "Shaking or stirring"? A case-study of physical education teacher education in Norway. Dissertation from the Norwegian School of Sport Sciences.

Nes, B. M., Østhus, I. B. Ø., Welde, B., Aspenes, S. T. \& Wisløf, U. (2013). Peak Oxygen Uptake and Physical Activity in 13- to 18-year-Olds: The Young HUNT study. Medicine and Science in Sports and Exercise, 45(2), 304-313.

Olafson, L. (2002). I Hate Phys. Ed.: Adolescent Girls Talk About Physical Education. Physical Educator, 59(2), 67-74.

Ommundsen, Y. (2013). Fysisk-motorisk ferdighet gjennom kroppsøving - et viktig bidrag ttil elevenes allmenndanning og læring i skolen. Norsk Pedagogisk Tidsskrift, 97, 155-166.

Ommundsen, Y. \& Kvalø, S. E. (2007). Autonomy-Mastery, Supportive or Performance Focused? Different teacher behaviours and pupils' outcomes in physical education. Scandinavian fournal of Educational Research, 51(4), 385-413.

Postholm, M. B. (2010). Kvalitativ metode: en innføring med fokus på fenomenologi, etnografi og kasusstudier. Oslo: Universitetsforlaget.

Rishovd, T. (2013). Sosial samanlikning $i$ kroppsøving: Ein kvantitativ studie om jenter og gutar sine referansemønster $i$ kroppsøvingsfaget på ungdomsskulen. (Masteroppgave) Pedagogisk institutt, NTNU. Trondheim: Norges Teknisk Naturvitenskaplige Universitet.

Ryan, R. M. \& Deci, E. L. (2000). Self-Determination Theory and the Facilitation of Intrinsic Motivation, Social Development, and Well-Being. American Psychologist, 55(1), 68-78.

Ryan, R. M. \& Deci, E. L. (2001). On Happines and Human Potentials: A Review of Research on Hedonic and Eudaimonic Well-Being. Annual Review of Psychology, 521(1), 141-166.

Seippel, Ø. (2005). Orker ikke, gidder ikke, passer ikke? Om frafallet $i$ norsk idrett. Rapport 2005: 3, Institutt for samfunnsforskning, Oslo.

Säfvenbom, R., Haugen, T. \& Bulie, M. (2014). Attitudes toward and motivation for PE: who collects the benefits of the subject? Physical Education and Sport Pedagogy, DOI: 10.1080/17408989.2014.892063

Tillaar, R., Rangul, V. \& Lagestad, P. (2016). Effekten av økt fysisk aktivitet i skolen. Nordisk tidsskrift for pedagogikk og kritikk, 2, 108-118.

Utdanningsdirektoratet (2015). Læreplan i kroppsøving. Hentet fra: http://www.udir.no/k106/KRO1-03/Hele/

Ward, J., Wilkinson, C., Graser, S.V. \& Prusak, K.A. (2008). Effects of choice on student motivation and physical activity behavior in physical education. Fournal of Teaching in Physical Education, 27(3), 385-98.

Åstrand, P.O., Rodahl, K. \& Strømme, S.B. (2003). Textbook of Work Physiology-Physiological Bases of Exercise, 4th Edition. Canada: Human-Kinetic. 